\title{
PKM PELATIHAN PEMASARAN DAN PRANOTO MONGSO \\ TANAMAN HIDROPONIK PADA KELURAHAN BLABAK, PESANTREN, KOTA KEDIRI
}

\author{
Ema Nurzainul Hakimah"), Restin Meilina ${ }^{2)}$, Farida Nurlaila Zunaidah ${ }^{3)}$ \\ ${ }^{1}$ Program Studi Manajemen, Fakultas Ekonomi, Universitas Nusantara PGRI \\ Kediri \\ emahakimah@unpkediri.ac.id \\ ${ }^{2}$ Program Studi Manajemen, Fakultas Ekonomi, Universitas Nusantara PGRI \\ Kediri \\ restin@unpkediri.ac.id \\ ${ }^{3}$ Program Studi Pendidikan Biologi, FKIP, Universitas Nusantara PGRI Kediri \\ faridanurlaila8889@gmail.com
}

\begin{abstract}
ABSTRAK
Kegiatan ini dilatarbelakangi kurang optimalnya program KRPL dari dinas pertanian, dimana sejauh ini implementasi program tersebut belum dirasakan oleh keseluruhan warga kelurahan Blabak. Selain itu, pendampingan untuk kemandirian warga setelah program tersebut selesai masih kurang, terutama terkait teknologi regenerasi tanaman, teknologi pola tanam, teknologi pasca panen, dan strategi pemasarannya. Tujuan dari kegiatan ini adalah (1) Memberikan pelatihan dan Bimbingan teknis (Bintek) tentang teknologi budidaya tanaman hidroponik (2) Memberikan pendampingan dalam mengorganisir pola tanam dan pola panen (pranoto mongso) tanaman hidroponik (3) Memberikan Pelatihan dan Bimbingan teknis tentang manajemen pemasaran produk, pengemasan produk, meningkatkan harga jual produk dan pemasaran e-commerce; dan (4) Mewujudkan pemberdayaan masyarakat yang memiliki kemandirian ketika program pendampingan selesai. Metode yang kami pilih untuk mencapai tujuan tersebut antara lain dengan bimbingan teknis, sosialisasi, kolaborasi, partisipasi, dan pembangunan infrastruktur hidroponik yang didalamnya terdapat kegiatan praktek langsung oleh warga tentang bercocok tanam hidroponik, merancang strategi pemasaran, dan rencana lanjutan pendampingan kelompok yang dibentuk oleh warga. Kegiatan ini bermitra dengan Pokja 4 TPPKK Kelurahan Blabak yang membidangi lingkungan hidup dan Posyandu karena membutuhkan sayuran sehat untuk pemberian makanan bayi dan anak. Dari kegiatan yang telah dilakukan diperoleh hasil: (1) Lahan kosong untuk fasum di perumahan villa bulurejo dimanfaatkan untuk pembuatan greenhouse hidroponik. Media hidroponik terdiri dari 2 modul yaitu pipa paralon dengan 329 titik tanam dan asbes dengan total 728 titik tanam (2) kegiatan ini dapat menambah pengetahuan warga tentang pemasaran dan pranoto mongso tanaman hidroponik. (3) terbentuk kelompok warga yang mengelola penyemaian, pemberian nutrisi, pemindahan ke modul, pemanenan, dan pemasaran hasil tanaman hidroponik.

Kata kunci: KRPL, Hidroponik, Pranoto Mongso
\end{abstract}




\begin{abstract}
This community service was done because of the implementation of KRPL program from agriculture department which not perceived by the whole of Blabak Village. Otherwise, the less of effort to increase self capability when the program finished especially in plant regeneration technology, planting technology, postharvest technology, and marketing strategis. The purpose of this action is (1) provide training and technical guidance on hydroponic cultivation technology, (2) provide mentoring in organizing cropping patterns and harvest patterns (pranoto mongso) hydroponic plants, (3) provide training and technical guidance in management of product marketing, product packaging, increasing product selling price, and e-commerce marketing, and (4) manifest the empowerment of community who have a self capability when the program is completed. To reach those purpose, we use some methode such as: technical guidance, socialization, collaboration, participation, and provide hydroponics infrastructure in which there are direct practice activities by all participants on hydroponic cultivation, marketing strategy, and follow up plans for community groups. This program is in partnership with Pokja 4 TPKK Blabak Village who work in living environmental sector, and Posyandu who need healthy vegetables for feeding baby and child. The result of this programe are : (1) free land for public facilities in villa bulurejo residence utilized for hydroponic green house. Hydroponic media consist of 2 modules, paralon pipes with 329 planting points and asbestos with 728 planting points, (2) this programe can increase community's knowledge about marketing and pranoto mongso hydroponic plants, (3) this program formed community groups that manage seeding, nutrition, transfer to modules, harvesting, and marketing of hydroponic plants.
\end{abstract}

Keywords: KRPL, Hydroponic, Pranoto Mongso

\title{
PENDAHULUAN
}

Kebutuhan pangan merupakan salah satu kebutuhan primer manusia. Pemenuhan kebutuhan akan pangan menjadi dasar dalam menentukan kualitas generasi sebuah bangsa (Ashari et. al: 2012). Salah satu pemenuhan pangan yang berkualitas adalah dengan konsumsi sayuran. Memenuhi kebutuhan akan sayuran sebenarnya bukanlah hal yang sulit. Setiap keluarga dapat memanfaatkan pekarangan di sekitar rumah mereka untuk menghasilkan sayuran. Roidah (2014) secara singkat mendefinisikan pekarangan sebagai sebidang tanah darat yang terletak di sekitar rumah dan jelas batas-batasnya. Pekarangan dapat difungsikan sebagai lumbung hidup, warung hidup dan apotik hidup.

Pemanfaatan lahan pekarangan sebagai sumber pangan lestari sudah diupayakan oleh dinas pertanian melalui program KRPL (Kawasan Rumah Pangan Lestari), namun demikian upaya ini tentu bukan hanya menjadi tanggung jawab 
pemerintah tetapi harus mendapat dukungan secara aktif dari masyarakat khususnya keluarga sebagai pemerintahan terkecil dari sebuah Negara (Dwiratna et al, 2016).

Pada kelurahan Blabak yang terdiri dari 4 lingkungan (Balekambang, Jegles, Pagut, dan Bulurejo), program KRPL hanya dilaksanakan di lingkungan Balekambang dengan harapan dapat menjadi percontohan bagi lingkungan lain. Program tersebut selama ini sudah membantu mengupayakan pemanfaatan pekarangan dengan menyediakan bibit, memberi penyuluhan tentang cara menanam, menyiram dan memupuk. Secara nyata program ini dirasa kurang dalam pendampingan untuk regenerasi tanaman, pengaturan pola tanam, dan teknologi pasca panen. Sehingga ketika program ini selesai masyarakat tetap tidak dapat mandiri, masih banyak yang tergantung pada pemberian bibit dari dinas, dan berproduksi hanya untuk kebutuhan sayur keluarga tanpa berpikir untuk menjadikannya usaha yang bernilai ekonomis. Hal ini juga yang menyebabkan lingkungan lain di kelurahan Blabak belum dapat mengikuti dan mencontoh program KRPL dari lingkungan Balekambang.

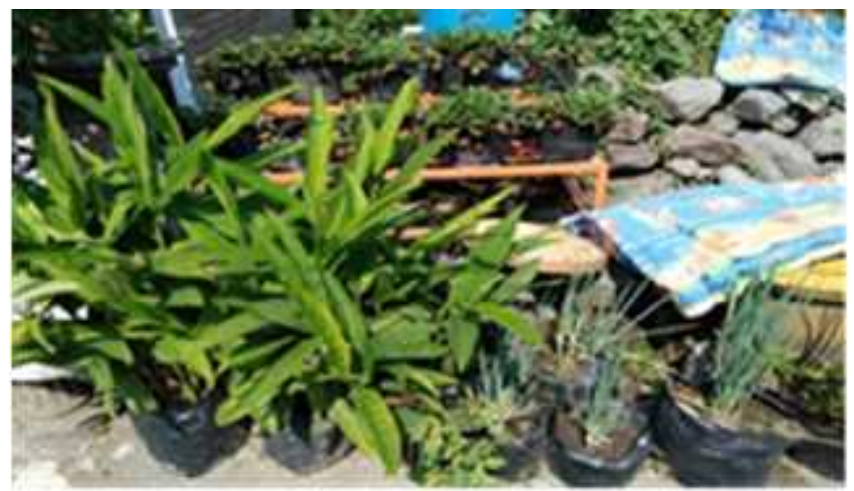

Gambar 1 : Pelaksanaan Program KRPL

Gambar di atas menunjukkan fasilitas rangka besi dan bibit dari program KRPL di salah satu warga lingkungan Balekambang, Kelurahan Blabak, Kota Kediri. Orientasi sejauh ini hanya untuk konsumsi sendiri, sehingga tidak ada upaya untuk menambah nilai jual dari tanaman. Roidah (2014), mengemukakan bahwa hasil dari pekarangan dapat memberikan sumbangan $25 \%$ pendapatan bagi petani miskin, apabila tanaman yang dibudidayakan dikelola secara baik kemanfaatan ini dapat dinikmati secara berkesinambungan (Ashari et.al : 2012).

Di kelurahan blabak, terdapat 5 kompleks perumahan dari pengembang (developer) yang berbeda-beda. Salah satu perumahan dengan jumlah kepala 
keluarga (KK) yang paling banyak $( \pm 84 \mathrm{KK})$ adalah Perumahan Villa Bulurejo. Lahan pekarangan yang sempit adalah keadaan nyata bagi masyarakat yang tinggal di daerah perumahan dan perkotaan pada umumnya. Kondisi lahan yang sempit mengakibatkan tanah sebagai media tanam menjadi sangat mahal dan menjadi pertimbangan bagi warga untuk bercocok tanam. Hal ini juga yang dialami oleh warga perumahan villa bulurejo. Selain masalah keterbatasan lahan dan penguasaan cocok tanam dengan media tanam berupa tanah, mereka juga mempunyai keterbatasan pengetahuan tentang cocok tanam dengan media selain tanah, dan

pengetahuan dari aspek pemasaran. Hal inilah yang mendasari pemilihan tempat pengabdian masyarakat dilakukan di perumahan Villa Bulurejo.

Pengabdian masyarakat ini bermitra dengan Kelompok Kerja 4 TPPKK dan Posyandu Menur 8 yang juga berlokasi di Perumahan Villa Bulurejo. Hasil diskusi dan observasi dengan mitra diperoleh data-data sebagai berikut:

Tabel 1 : Karakteristik Mitra

\begin{tabular}{|c|c|c|c|}
\hline No. & Uraian & Prosentase & Keterangan \\
\hline 1. & $\begin{array}{l}\text { Pendidikan: } \\
\text { a. SMA } \\
\text { b. Sarjana }\end{array}$ & $\begin{array}{l}60 \% \\
40 \% \\
\end{array}$ & $\begin{array}{l}\text { Memiliki kemampuan yang } \\
\text { memadai untuk berkembang }\end{array}$ \\
\hline 2. & $\begin{array}{l}\text { Usia: } \\
\text { a. }<25 \text { tahun } \\
\text { (anak/balita/usia } \\
\text { sekolah) } \\
\text { b. } 25-35 \text { tahun } \\
\text { c. }>35-45 \text { tahun }\end{array}$ & $\begin{array}{l}85 \% \\
5 \%\end{array}$ & Usia yang sangat produktif \\
\hline 3. & $\begin{array}{l}\text { Rumah Tangga Muda } \\
\text { dengan } 2 \text { anak balita/ } \\
\text { usia sekolah dasar }\end{array}$ & $96 \%$ & $\begin{array}{l}\text { Selalu memasak } 2 \text { menu } \\
\text { sayuran, untuk anak dan } \\
\text { orang tua }\end{array}$ \\
\hline 4. & $\begin{array}{l}\text { Pekerjaan Ibu-ibu } \\
\text { a. Ibu Rumah Tangga } \\
\text { b. Guru/ Dosen/ } \\
\text { Karyawan Swasta }\end{array}$ & $\begin{array}{l}90 \% \\
10 \%\end{array}$ & $\begin{array}{l}\text { Ibu rumah tangga memiliki } \\
\text { banyak waktu luang }\end{array}$ \\
\hline
\end{tabular}

Sumber: data primer, 2017

Berdasarkan informasi diatas diperoleh beberapa fakta bahwa warga ingin memberikan makanan yang sehat dan memenuhi kebutuhan gizi bagi anak-anak 
mereka yang dalam masa pertumbuhan/usia sekolah, melakukan penghematan dalam belanja kebutuhan sehari-hari karena rata-rata dan hampir semua rumah tangga mereka memasak dua jenis masakan yaitu pedas dan tidak pedas untuk anakanak balita mereka, dan ada keinginan juga untuk memanfaatkan waktu luang mereka dengan melakukan hal produktif seperti bercocok tanam sayuran, menghijaukan pekarangan dan menambah pendapatan keluarga. Selain itu, pengurus Posyandu Menur 8 dan Pokja 4 TPPKK secara terpisah menyampaikan bahwa mereka sangat ingin melakukan penghematan anggaran belanja khususnya untuk program pemberian makan bayi dan anak, bantuan gizi buruk balita dan sekaligus ingin mempunyai pendapatan tambahan untuk organisasi, misalnya dapat menjual hasil sayurnya ke pasar tradisional, moderen maupun dengan e-commerce. Keinginan dan harapan warga ini bukan tanpa alasan, karena kelurahan Blabak berdekatan dengan tiga pasar tradisional besar (pasar Centong, pasar Blabak, pasar Bence), pasar Grosir Kota Kediri dan tiga hipermarket (Golden, TransMart Carrefour, dan Hypermart) yang tentu mempunyai permintaan akan sayur yang tinggi. Untuk itu mereka menghadapi masalah yaitu minimnya wawasan dan ilmu mereka tentang pemasaran, pengemasan, strategi promosi dan bagaimana menciptakan value added terhadap hasil produksinya. Kedepannya mereka berharap dapat menjadi organisasi yang mandiri dan tidak tergantung penuh pada KRPL dan dana Prodamas pemerintah Kota Kediri.

Berdasarkan permasalahan-permasalahan diatas, pengabdian pada masyarakat ini bertujuan untuk:

1. Memberikan pelatihan dan Bimbingan teknis (Bintek) tentang teknologi budidaya tanaman hidroponik

2. Memberikan pendampingan dalam mengorganisir pola tanam dan pola panen (pranoto mongso) tanaman hidroponik

3. Memberikan Pelatihan dan Bimbingan teknis tentang manajemen pemasaran produk, pengemasan produk, meningkatkan harga jual produk dan pemasaran e-commerce; dan

4. Mewujudkan pemberdayaan masyarakat yang memiliki kemandirian ketika program pendampingan selesai. 


\section{METODE PELAKSANAAN}

Program pengabdian masyarakat ini dilaksanakan selama 8 bulan dimulai pada bulan januari 2018 hingga bulan agustus 2018. Tempat pelaksanaan pada perumahan villa Bulurejo yang beralamat di jalan Bulurejo, Kelurahan Blabak, Kecamatan Pesantren, Kota Kediri. Kegiatan ini bermitra dengan ibu-ibu kelompok kerja (Pokja) 4 TPPKK Kelurahan Blabak yang membidangi lingkungan hidup dan Posyandu (pos pelayanan terpadu) karena membutuhkan sayuran sehat untuk PMBA (pemberian makanan untuk bayi dan anak).

Metode kegiatan yang akan dilakukan untuk tercapainya tujuan pengabdian kepada masyarakat ini adalah metode bimbingan teknis, sosialisasi, kolaborasi, partisipasi, dan pembangunan infrastruktur hidroponik yang didalamnya terdapat kegiatan praktek langsung oleh warga tentang bercocok tanam hidroponik, merancang strategi pemasaran, dan rencana lanjutan pendampingan kelompok yang dibentuk oleh warga. Dasar pelaksanaan adalah evaluasi awal sebagai landasan untuk menentukan posisi pengetahuan kelompok sasaran mengenai bercocok tanam khususnya hidroponik, mindset mitra dalam berwirausaha, dan komitmen mereka untuk melanjutkan kegiatan setelah masa pendampingan selesai.

\section{HASIL DAN PEMBAHASAN}

\section{Instalasi atau Pemasangan Infrastruktur Hidroponik}

Kegiatan pengabdian masyarakat ini diawali dengan melakukan observasi, penjajagan dan diskusi awal dengan mitra di lokasi perumahan Villa Bulurejo, Kelurahan Blabak, Kota Kediri Diskusi awal ini diarahkan untuk menyiapkan lokasi yang tepat untuk membangun infrastruktur hidroponik. Dari pertemuan ini, diperoleh lokasi hidroponik yaitu lahan kosong yang merupakan fasilitas umum (fasum) perumahan dan sebenarnya diperuntukkan untuk taman namun lebih banyak ditumbuhi rumput (tanaman liar) sehingga tampak mengganggu.

Proses dimulai dengan pekerjaan awal yaitu pembersihan, perataan tanah, dan pembuatan plesteran. Kemudian pekerjaan dilanjutkan dengan pemasangan rangka galvalum untuk green house dan pemasangan plastik UV untuk atap serta pemasangan jaring insecnet mengelilingi greenhouse. Tahap pekerjaan awal selesai 
dengan instalasi modul hidroponik dari pipa paralon, asbes dan sterofoam, pemasangan tandon, instalasi air dan listrik serta pembuatan meja semai.
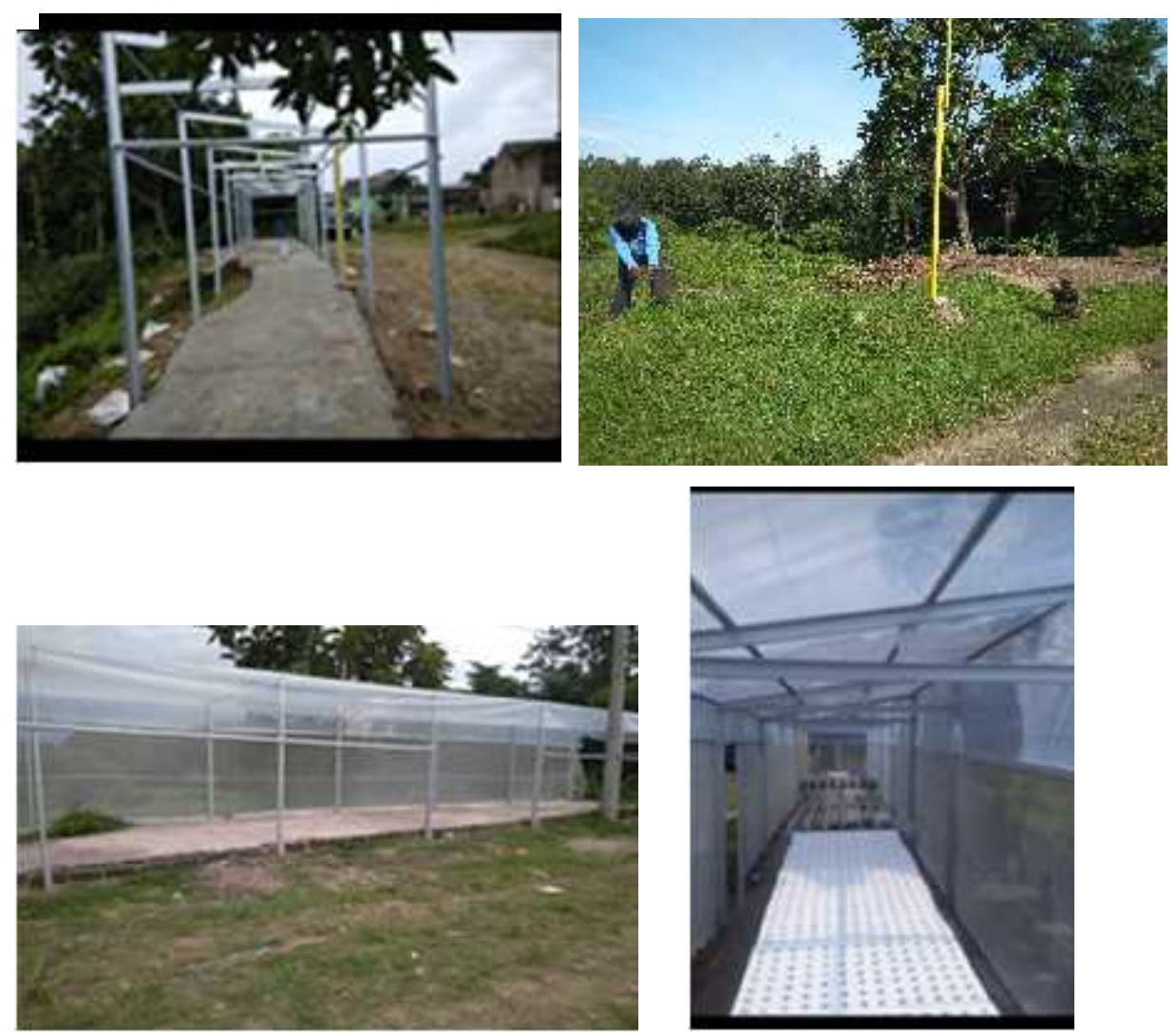

Gambar 2: Pekerjaan Pemasangan Infrastruktur Hidroponik

Media hidroponik terdiri dari 2 modul yaitu modul pipa paralon dengan 329 titik tanam dan modul asbes dikombinasi dengan mulsa dan sterofoam dengan total 728 titik tanam.

Modul asbes digunakan untuk pemindahan hasil semai usia 1-2 minggu, sedangkan modul pipa paralon digunakan untuk pembesaran tanaman hingga siap panen.

\section{Kegiatan Pelatihan, Bimbingan Teknis, dan Pendampingan}

Setelah green house dan modul hidroponik siap digunakan, kegiatan selanjutnya dari pengabdian masyarakat ini adalah pelatihan, bimbingan teknis, dan pendampingan teknik hidroponik, termasuk mengorganisir pola tanam dan pola panen (pranoto mongso) serta manajemen pemasaran hasil panennya. Kegiatan ini dilaksanakan di outdor dengan mendirikan tenda pertemuan di samping green 
house hidroponik. Hal ini dilakukan karena di lingkungan perumahan Villa Bulurejo ini tidak ada gedung atau balai pertemuan.

Untuk materi hidroponik disampaikan oleh Bapak Dhian Dwi Nur Wenda, M.Pd yang merupakan dosen prodi PGSD Universitas Nusantara PGRI Kediri sekaligus merupakan praktisi yang sudah bertahun-tahun menekuni budidaya hidroponik. Materi hidroponik pertama adalah penyemaian bibit, dimulai dari menyiapkan media tanam, bibit tanaman tusuk gigi, baki, plastik gelap, karet ban, dan pengarahan tindakan selanjutnya yang harus dilakukan perserta setelah bibit disemaikan. Secara singkat tahap-tahap yang dilakukan oleh peserta selama pelatihan pertama (pelatihan penyemaian):

Alat dan bahan: Rockwool, bibit kangkung, bibit bayam merah, bibit sawi caisim, bibit sawi pok choy, tusuk gigi, baki, plastik, karet ban, bak air Langkah-langkah:

a. Potong rockwool berbentuk dadu ukuran $2.5 \times 2.5 \mathrm{~cm}$, kemudian rockwool direndam sebentar dengan air biasa lalu diangkat dan dikibaskan.

b. Membuat lubang untuk benih pada rockwool dengan menggunakan tusuk gigi, kemudian angkat benih dengan tusuk gigi, letakkan pada lubang rockwool yang telah dibuat

c. Setelah selesai benih ditata di baki, ditutupi dengan plastik hitam dan baki diikat dengan karet ban untuk menghindari cahaya matahari.

Pelatihan hidroponik selanjutnya dilakukan setelah benih sprout atau pecah. Langkah-langkah yang harus dilakukan selanjutnya dalam teknik hidroponik setelah benih sprout atau pecah yaitu:

a. Ketika benih sudah mulah pecah atau sprout ( $\pm 2-3$ hari), benih dijemur di meja semai dalam green house dan disiram secara berkala untuk menjaga agar rockwool tidak kering. Ketika tanaman sudah berdaun empat bisa dipindah di modul asbes serta diberikan nutrisi. 


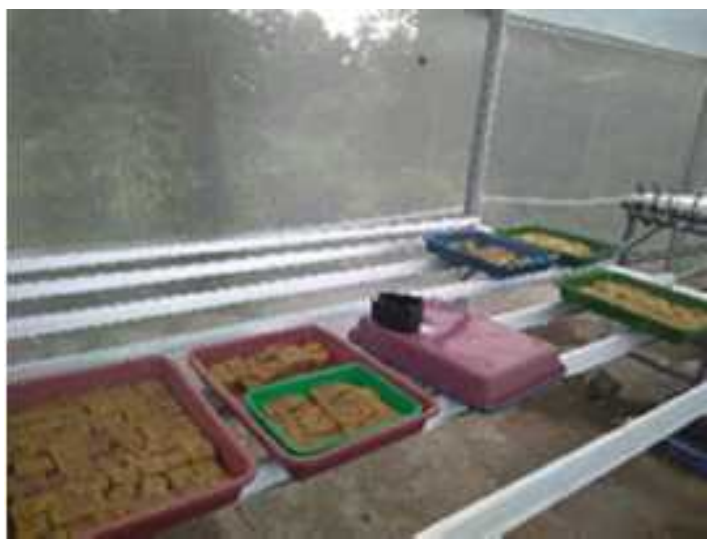

Gambar 3: Proses setelah benih pecah dan di jemur di meja semai

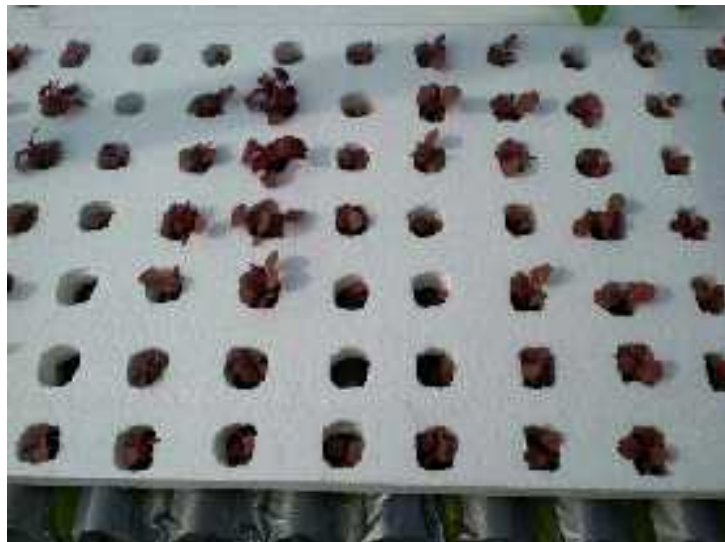

Gambar 4: Proses pemindahan setelah tanaman berdaun 4 ke modul asbes

b. Menyiapkan air bersih dalam wadah untuk pemberian nutrisi dengan catatan dalam setiap satu liter air, tambahkan $5 \mathrm{ml}$ Nutrisi A dan $5 \mathrm{ml}$ Nutrisi B.

c. Setelah tanaman cukup besar, harus dipindah ke modul paralon hingga siap untuk dipanen
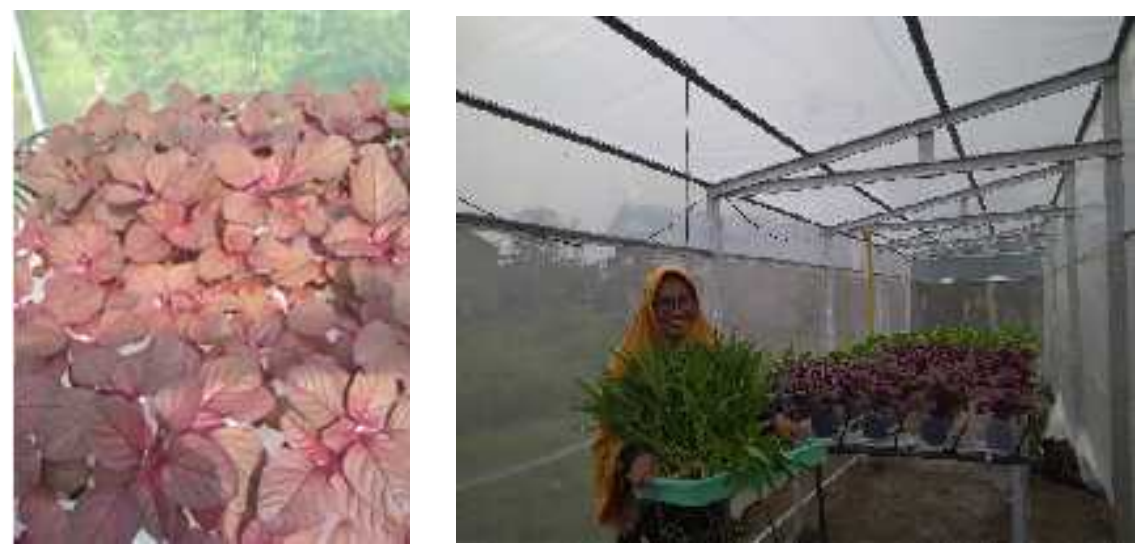

Gambar 5: Proses pembesaran hingga pemanenan di modul paralon 
Total waktu yang diperlukan untuk pelatihan, bintek, dan pendampingan teknik menanam hidroponik kurang lebih selama 2 bulan. Hasil dari pelatihan ini adalah pemahaman teknik serta masa tanam hingga panen tanaman hidroponik. Dari pemahaman tersebut, dapat dibentuk pola pranoto mongso hidroponik yaitu:

1. Tahap pertama adalah penyemaian, tahap ini dilanjutkan hingga benih pecah atau sprout dengan waktu 2-3 hari dan selanjutnya dijemur di meja semai.

2. Tahap kedua adalah pemindahan ke modul asbes, dilakukan setelah tanaman berdaun 4. Proses ini dilakukan saat usia tanaman 1 minggu dari waktu menyemai. Hal ini berarti seminggu setelah menyemai bibit, meja semai sudah kosong sehingga harus mulai menyemai lagi.

3. Tahap ketiga adalah pemindahan tanaman dari modul asbes untuk proses pembesaran di modul paralon. Proses ini dilakukan ketika usia tanaman 2-3 minggu dari waktu menyemai atau 1-2 minggu setelah proses pemindahan dari meja semai ke modul asbes.

4. Tahap keempat adalah proses panen. Proses ini dilakukan ketika usia tanaman 4-5 minggu dari waktu menyemai, atau 2-3 minggu setelah tanaman dipindah dari modul asbes ke modul paralon.

Setelah pendampingan untuk teknik penanaman hidroponik, peserta diberikan pelatihan dan pendampingan untuk manajemen pemasaran hasil panen meliputi pengemasan produk, meningkatkan harga jual produk dan pemasaran $e$ commerce. Pelatihan manajemen pemasaran diberikan oleh Ibu Ema Nurzainul Hakimah, M.M. yang merupakan dosen prodi manajemen Universitas Nusantara PGRI Kediri yang sudah tersertifikasi di bidang manajemen pemasaran serta berpengalaman dalam pelatihan pemasaran hidroponik dimana salah satu hasilnya sudah dipublikasikan di jurnal Abdinus (2017) berjudul "Pemberdayaan Masyarakat Melalui Pelatihan Hidroponik Membentuk Wirausahawan Baru Pada Perum Kuwak Utara Kelurahan Ngadirejo Kota Kediri”. Tahapan pelatihan pemasaran yaitu:

1. Peserta diberikan tambahan wawasan tentang ilmu pemasaran khususnya pemasaran produk barang, dimana terdapat bauran pemasaran barang yang pada masing-masing bauran tersebut harus diberikan polesan sebagai nilai jual. Mitra harus mengetahui bahwa komoditas yang mereka budidayakan ini adalah 
komoditas tanaman sayur yang mempunyai nilai kompetitif, sehingga harus dikenali dengan baik segmen, target dan positioning yang tepat. Produk harus diberi label merek yang mempunyai nilai jual, mudah dilafalkan, mudah diingat dan menjadi merek satu-satunya di dunia. Pemberian nama dagang dan kemasan, menjadi bagian pamungkas dari produksi yang sekaligus memberikan pencitraan pada produk sebelum akhirnya produk sampai di tangan konsumen.

2. Design stiker untuk brand produk, terdiri dari stiker gelang untuk penjualan sayur dengan kemasan ikat (misalnya untuk sayur bayam dan kangkung), dan stiker tempel untuk di tempel di kemasan plastik.

3. Pelatihan pengemasan produk
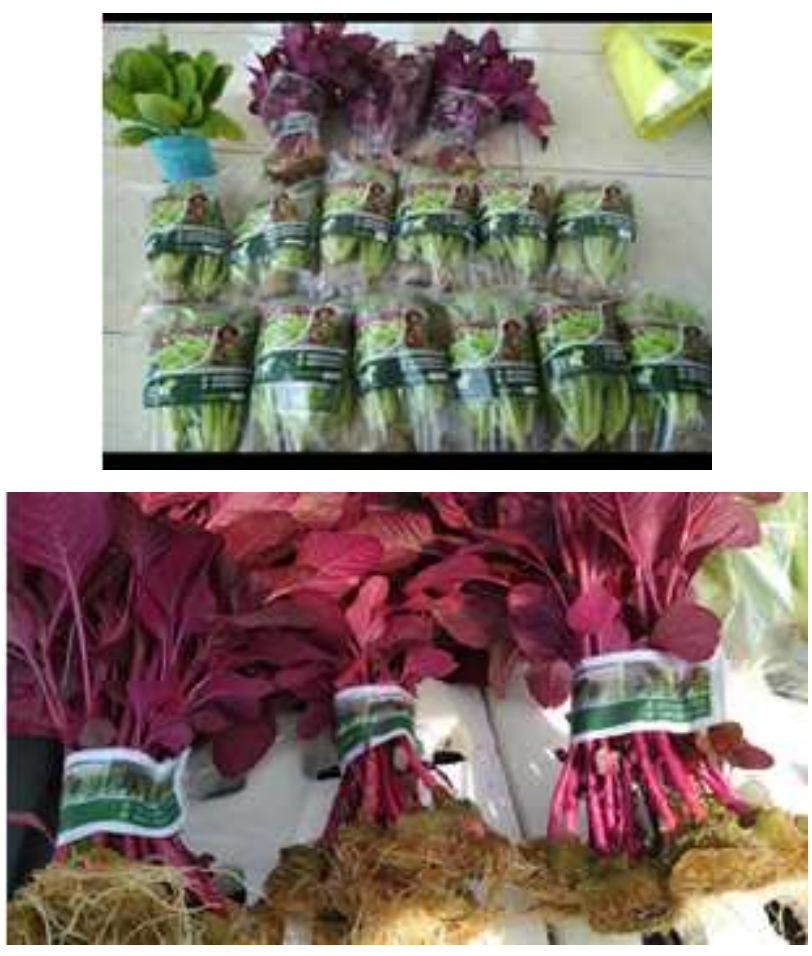

Gambar 6: Teknik pengemasan produk hasil hidroponik

4. Pemilihan media promosi dan pemasaran yang tepat sangat menentukan keberhasilan penjualan. Mengingat titik media tanam yang dimiliki mitra tidak banyak, maka dibutuhkan kontinyuitas dan pranoto mongso yang sangat baik. Dengan kelemahan titik tanam yang terbatas maka kami menyarankan kepada mitra untuk pemasarannya berdasarkan by order dan harus membangun jaringan pemasaran atau kemitraan dengan petani hidroponik lainnya di Kediri. Pada saat 
ini mitra hanya dimungkinkan melakukan promosi dengan menggunakan media sosial seperti facebook, whatsapp, dan instagram yang sering digunakan oleh mitra dalam berkomunikasi. Memanfaatkan relasi, teman dan kelompoknya untuk mendapatkan pembeli rutin dan penyampainan pesan iklan ini dilakukan 1 atau 2 minggu sebelum panen. Penjualan berdasarkan pesanan menjadi teknik awal dalam memasuki pasar. Penjelasan media pemasaran dan teknik pemasaran ini didahului oleh strategi penetapan harga, hal ini dilakukan mengingat mitra belum memahami strategi penetapan harga, sehingga harga tersebut mampu memberikan citra bagi usaha mereka yang bercirikan sosioentrepreneur. Untuk jangka panjang, kami telah menyampaikan bahwa sangat terbuka peluang bisnis hidroponik di Kediri. Peluang besar pemasaran produk hidroponik mitra ini akan terbuka jika mereka kuat dalam kontinyuitas dan kemitraan antar anggota. Dengan melakukan kontrak dengan supermarket di Kediri (Golden, transmart, hypermart), dan kontrak dengan hotel-hotel berbintang di Kediri, maka keutungan usaha pasti akan mereka nikmati. Secara perseorangan dan organisasi yaitu terpenuhinya kebutuhan sayuran sehat skaligus pendapatan tambahan bagi organisasi PKK dan Posyandu.

\section{Rencana Tindak Lanjut Pembentukan Kelompok Wanita Tani}

Untuk menjamin keberlanjutan atau kontinyuitas dari program pengabdian masyarakat ini, diharapkan terbentuk kelompok warga yang bertanggungjawab dalam manajemen tanaman hidroponik ini. Kelompok tersebut harus mampu mengorganisir rutinitas kegiatan menanam, merawat, memanen, hingga memasarkan produk hidroponik. Untuk memfasilitasi pembentukan kelompok tersebut, kegiatan pengabdian masyarakat ini mengundang Bapak Agus Fatoni Tohari, SP dari Dinas Ketahanan Pangan dan Pertanian Kota Kediri. Beliau memberikan penjelasan dan pendampingan untuk pembentukan kelompok wanita tani yang merupakan program dari pemerintah. Dengan program tersebut, kelompok warga yang mengorganisir hidroponik akan tergabung dalam kelompok wanita tani yang organisasinya disahkan oleh Kemenkumham. Nantinya, kelompok wanita tani difasilitasi bantuan dari dinas pertanian pusat sesuai proposal permohonan bantuan yang diajukan. 
Dari pelatihan ini, terbentuk kelompok warga yang terstuktur, dengan penjadwalan dan pembagian tugas mulai dari penyemaian, pemberian nutrisi, pemindahan ke modul, pemanenan, dan pemasaran hasil tanaman hidroponik. Tahap rencana tindak lanjut adalah penyusunan proposal pengajuan ke dinas pertanian untuk pengesahan kelompok tersebut menjadi kelompok wanita tani.

\section{Indikator Keberhasilan Pelatihan}

Untuk mengetahui keberhasilan pelatihan dan bintek dalam pengabdian masyarakat ini perlu dilakukan evaluasi kegiatan. Adapun cara evaluasinya adalah dengan membandingkan pengetahuan dan pemahaman peserta sebelum dan sesudah pelatihan mulai dari teknik hidroponik hingga pemasaran. Secara umum hasil evaluasi menunjukkan adanya peningkatan pengetahuan peserta, ditunjukkan pada saat praktik semua bisa melakukan dengan mandiri, dapat membuat rencana pemasaran, dan mampu menjelaskan kembali saat diberi pertanyaan. Tabel 2 berikut ini menunjukkan kriteria dan indikator keberhasilan kegiatan pengabdian masyarakat ini.

Tabel 2: Indikator keberhasilan kegiatan

\begin{tabular}{|l|l|l|}
\hline No. & \multicolumn{1}{|c|}{ Kriteria } & \multicolumn{1}{c|}{ Indikator } \\
\hline 1. & Tingkat partisipasi & $\begin{array}{l}\text { Kegiatan pelatihan dan workshop selalu dipenuhi } \\
\text { peserta karena tingkat kehadiran mencapai 100\% } \\
\text { sesuai dengan jumlah undangan yang disebarkan. }\end{array}$ \\
\hline 2. & $\begin{array}{l}\text { Tingkat } \\
\text { pemahaman peserta } \\
\text { terhadap materi } \\
\text { pelatihan }\end{array}$ & $\begin{array}{l}\text { Tampak adanya peningkatan pemahaman tentang } \\
\text { teknik hidroponik, dan pemasaran. Peserta aktif } \\
\text { dalam diskusi, tanya jawab, menyampaikan ide dan } \\
\text { mampu mempraktikkan dengan baik. Peserta } \\
\text { sangat serius dan antusias mengikuti dari awal } \\
\text { acara hingga selesai. }\end{array}$ \\
\hline 3. & $\begin{array}{l}\text { Dampak } \\
\text { penyuluhan }\end{array}$ & $\begin{array}{l}\text { Peserta mampu mempraktikkan bertanam } \\
\text { hidroponik dan mempunyai ide tentang cara } \\
\text { pemasaran untuk produk yang dihasilkan. }\end{array}$ \\
\hline 4. & Kesesuaian materi & $\begin{array}{l}\text { Peserta berpendapat bahwa materi pelatihan sangat } \\
\text { kekinian (hidroponik menjadi trend dan mampu } \\
\text { menyediakan bahan pangan yang organik). Cara } \\
\text { penyampaian yang lugas dan komunikatif } \\
\text { memudahkan dan menarik peserta untuk mengikuti } \\
\text { dan memahami materi. }\end{array}$ \\
\hline
\end{tabular}

Sumber: Data primer, 2018 


\section{Faktor Pendorong dan Penghambat Kegiatan}

Secara umum kegiatan pengabdian ini berhasil jika dilihat dari beberapa indikator tersebut diatas, Ada beberapa faktor yang menjadi pendorong keberhasilan acara ini, yaitu bahwa kegiatan ini dirancang dengan keterlibatan yang tinggi dari mitra pengabdian. Permasalahan yang diangkat dan diidentifikasi diperoleh secara langsung sehingga warga sangat antusias ketika mengikuti setiap tahap pengabdian masyarakat meskipun dengan jadwal yang padat. Narasumber yang memberikan pelatihan memiliki kemampuan komunikasi yang sangat baik sehingga bisa menyatu dengan peserta baik secara formal maupun informal, disamping itu yang bersangkutan merupakan orang-orang yang memang menguasai materi secara keilmuan dan praktik.

Faktor yang menjadi penghambat adalah sarana untuk presentasi yang kurang baik, karena dilakukan di outdoor, tidak tersedia layar untuk menampilkan materi presentasi dan cuaca yang sangat panas sedikit mengganggu konsentrasi peserta.

\section{KESIMPULAN}

Hasil kegiatan pengabdian masyarakat ini dapat disimpulkan sebagai berikut :

1. Lahan kosong untuk fasum di perumahan villa bulurejo dimanfaatkan untuk pembuatan greenhouse hidroponik. Media hidroponik terdiri dari 2 modul yaitu pipa paralon dengan 329 titik tanam dan asbes dengan total 728 titik tanam

2. Kegiatan ini dapat menambah pengetahuan warga tentang pemasaran dan pranoto mongso tanaman hidroponik. Hal ini meliputi cara menanam, memanen, mengatur pola tanam, waktu panen, dan waktu memasarkan.

3. Terbentuk kelompok warga yang mengelola penyemaian, pemberian nutrisi, pemindahan ke modul, pemanenan, dan pemasaran hasil tanaman hidroponik.

\section{DAFTAR PUSTAKA}

Ashari, Saptana, dan Purwantini, T.B. 2012. Potensi Dan Prospek Pemanfaatan Lahan Pekarangan Untuk Mendukung Ketahanan Pangan. Bogor: Pusat Sosial Ekonomi dan Kebikajan Pertanian 
Dwiratna, N.P.S., Widyasanti, A. , dan Rahmah, D.M. (2016). Pemanfaatan Lahan Pekarangan Dengan Menerapkan Konsep Kawasan Rumah Pangan Lestari. Jurnal Aplikasi Ipteks Untuk Masyarakat Dharmakarya. Vol. 5, No. 1, (online) diakses 7 Juni 2017

Hakimah, E.N., Sardanto, R., Subagyo. (2017). Pemberdayaan Masyarakat Melalui Pelatihan Hidroponik Membentuk Wirausahawan Baru Pada Perum Kuwak Utara Kelurahan Ngadirejo Kota Kediri. Jurnal Abdinus. Vol.1, No. 1, (Online), diakses 5 Januari 2018.

Roidah, I.S. (2014). Pemanfaatan Lahan Dengan Menggunakan Sistem Hidroponik. Jurnal Universitas Tulungagung Bonorowo. Vol. 1, No. 2, (online), diakses 7 Juni 2017. 